\title{
Implementation of Intangible Assets Accounting in the Ministry of Public Works and Public Housing Analysis
}

\author{
Aditya Aditya $^{1^{*}}$, Ayuningtyas Hertianti ${ }^{1}$ \\ ${ }^{1}$ Faculty of Economics and Business, Universitas Indonesia, Depok 16424, Indonesia \\ ${ }^{*}$ Corresponding Author: dhitiacorps@yahoo.com
}

\begin{abstract}
This research uses a case study that aimed to analyze the implementation of intangible asset accounting at the Ministry of Public Works and Public Housing (MoPWH), the weaknesses of intangible asset accounting implementation in the MoPWH, and providing solutions to overcome the weaknesses of intangible asset accounting implementation in the MoPWH. The analysis is conducted by comparing the conditions of the intangible asset accounting implementation in the MoPWH with the Government Accounting Standard Bulletin Number 17 on Accounting for Intangible Asset Based on Accruals. The results show that the weakness of the implementation of intangible assets accounting in the MoPWH is in the stage of recognition, measurement, termination and disengagement, recording, presentation and disclosure. The results suggest that the implementation of intangible asset accounting can be improved by drawing up standard guidelines for the implementation of intangible asset accounting in the MoPWH, preparing standard operating procedures (SOP) for the implementation of intangible asset accounting in the $\mathrm{MoPWH}$, improving the capacity of MoPWH employees and increasing the role of the Inspectorate General in the administration of intangible assets in the MoPWH.
\end{abstract}

Keywords: Accounting; Government Accounting Standards; Ministry of Public Works and Public Housing; Intangible Assets.

\section{INTRODUCTION}

The audit results of Supreme Audit Board of Indonesia in the Audited Financial Statements 2015 and the performance audit of Inspectorate General of MoPWH show the problems of inaccurate presentation and recording of intangible assets that affect the fairness of other asset presentation in the balance sheet of MoPWH which is potential to be overstated ${ }^{1}$.

The problems related to the management of intangible assets as described above are caused by the absence of standardized guidelines and Standard Operating Procedures (SOP) on the implementation of intangible asset accounting in the internal MoPWH. The issue of intangible assets has a unique complexity and is related to the accounting activities of assets.

Analysis of intangible asset accounting implementation in MoPWH is very important to do. This study attempts to provide an overview of the implementation of intangible asset accounting in the MoPWH and explores further how to optimize the implementation of the intangible asset accounting and formulate solutions to overcome the weakness of intangible asset accounting implementation in the MoPWH by using a case study approach.

This paper is organized as follows. In section 2, the literature review and intangible asset theory are given. In section 3, the method of designing the recommendation of solution and SOP based on theory and practice. The result of comparing the condition of the implementation of intangible assets in the MoPWH with Technical Bulletin Government Accounting Standard Number 17. Finally, our research is summarized in the last section of this paper.

\section{LITERATURE REVIEW Institutional Theory}

Institutional theory is the theory of how an organization adapts to its environment. Adjustment of an organization to be like another organization is called isomorphism ${ }^{2}$. Due to the pressure of isomorphism, organizations will become more uniform in certain respects and in accordance with the expectations of the institutional environment. DiMaggio and Powell $^{3}$ identified several organizational adjustments to institutional theory:

1) Categorical Adjustment, this happens when institutional rules direct organizations to build their structures ${ }^{3}$.

2) Structural Adjustment, this is caused by government regulations, environmental uncertainty, or seeking 
ıegıumacy. The organization will adopt a specific organizational structure ${ }^{3}$.

3) Procedural Adjustment, besides structure, organizations are affected to do things in several ways. Rationalization is done in the form of standard operating and organizational procedures ${ }^{3}$.

4) Personnel Adjustment, modern organizations have various specialization rules along with professional certificates. Adjustment to institutional rules is usually necessary to hire or use specific personnel ${ }^{3}$.

\section{Intangible Asset}

Statement of Government Accounting Standards Number 01 paragraph 56 regarding Presentation of Financial Statements defines that Intangible Assets are part of non-current assets that are used directly or indirectly for government activities or those used by the public ${ }^{4}$. In paragraph 66, intangible asset is a part of other non-current assets which are classified and presented as a group of other assets ${ }^{4}$. Technical Bulletin Government Accounting Standard Number 17 regarding Accounting for Intangible Assets Based on Accruals, defines intangible asset as non-financial assets that can be identified and have no physical form ${ }^{5}$. Intangible asset is owned for use in the production of goods or services, or used for other purposes including intellectual property rights ${ }^{5}$.

The criteria of an asset classified as intangible asset are identifiable that can be clearly separated and arise because of contractual or other legal agreements, government agencies can control and limit other parties, and have future economic benefits to generate revenue on goods, services, cash, or cash equivalent to the government.

The accounting treatment of intangible asset for government agencies in Indonesia is stipulated in Technical Bulletin Government Accounting Standard Number 17 includes recognition, measurement, termination and disengagement, recording, presentation, and disclosure. To be acknowledged as intangible assets, expenditures on an entity's activities should be able to: (1) meet the intangible asset definition, and (2) meet the recognition criteria $^{5}$. The intangible asset recognition criteria are that future economic benefits or potential services expected by the entity will be enjoyed, and the fair value or cost of the intangible asset can be measured reliably ${ }^{5}$.

According to Bunget et al., the management of intangible assets in the government sector becomes more important due to improving internal performance such as management control ${ }^{6}$. Management of a good intangible asset will be reflected in the financial statements resulting from the accounting process consisting of recognition, measurement, recording, presentation, and disclosure. The accounting treatment of intangible assets to date in various countries is still varied resulting in the resulting financial statements to be less reliable.

\section{Standard Operating Procedures (SOP)}

SOP as a document/instrument contains the processes and procedures of an activity that is effective and efficient based on a default standard. SOP function is to form regular, systematic and accounted work system and work flow; describes how the purpose of the work is carried out in accordance with applicable policies and regulations; explains how the process of conducting the activity takes place; as a means of ordering of the implementation and administration of daily work as defined methods; ensure consistency and systematic work processes; and establishing mutual relationships between work units. SOPs generally have a role in providing guidance on all activities undertaken in the organization effectively so as to help the organization achieve its goals, either short term or long term. Tathagati in his research showed a good change in the organization after applying SOP ${ }^{7}$.

\section{RESEARCH METHOD}

This research uses qualitative method with case study approach which try to explain presentation of intangible asset accounting in MoPWH. According to Sekaran ${ }^{8}$, one of considered suitable research for developing public sector accounting is a case study approach because case studies are the most flexible research techniques ${ }^{5}$. Case study research is also able to explore in detail and depth on a problem.

The data to be used as the basis of analysis in this study are primary data and secondary data. Primary data used is obtained through the existing data in the MoPWH associated with this research is through the method of observation and interviews with respondents. Interviews were conducted with officials and employees at the Bureau of State Property Management, the Financial Bureau, State Property Management officers and financial working unit, and the internal auditor of the MoPWH.

In addition, related data will also be obtained from the State Asset Management and Accounting Information System of the MoPWH, and documents related to the accounting of intangible assets such as the State Property Report, Financial Statements and Accountability Report Performance of Government Agencies. Secondary data is obtained by finding theories about the concepts of accounting of intangible assets from applicable legislation, accounting journals related to intangible accounting, books, and articles dealing with research topics.

The proportion of intangible asset in the balance sheet compared to the total assets owned by the MoPWH can be presented in Table 1.

The percentage of intangible asset value in 2014 amounted to $0.69 \%$ or equivalent to Rp5,110,211,396,598 of total assets owned by the MoPWH. While in 2015, the percentage increased by $0.07 \%$ to $0.76 \%$ or worth Rp6.194.191.615.930. 
Table.1. Intangible Asset Proportion in Balance Sheet of MoPWH

\begin{tabular}{cccc}
\hline Year & Total Asset & Intangible Asset & Persentage (\%) \\
\hline 2014 & 736.739 .354 .367 .739 & 5.110 .211 .396 .598 & 0,69 \\
2015 & 812.663 .149 .983 .472 & 6.194 .191 .615 .930 & 0,76 \\
\hline
\end{tabular}

The proportion of each type of intangible asset in the balance sheet of MoPWH of 2015 is presented in Table 2.

Table.2. Proportion by Type of Intangible Asset in Balance of MoPWH

\begin{tabular}{clcrr}
\hline No. & Intangible Asset Detail & Quantity & \multicolumn{1}{c}{ Value } & Percentage (\%) \\
\hline 1 & Copyright & 566 & $347,146,475.00$ & 0.01 \\
2 & Software & 1,973 & $74,625,000,324.00$ & 1.20 \\
3 & License & 804 & $1,547,454,500.00$ & 0.02 \\
4 & Research/Study Result & 5,962 & $3,823,750,422,734.00$ & 61.73 \\
5 & Other Intangible Asset & 4,756 & $2,293,921,591,897.00$ & 37.03 \\
& $\quad$ Total & 14,061 & $6,194,191,615,930.00$ & 100.00 \\
\hline
\end{tabular}

Of the total 14,061 units of intangible asset owned by the MoPWH with a value of Rp6,194,191,615,930, the order of percentage of intangible asset value from the largest is $61.73 \%$ Research/Study Results, Other Intangible Assets of $37.03 \%$, Software of $1.20 \%$, Licenses of $0.02 \%$, and Copyright by $0.01 \%$. In general, intangible asset MoPWH mostly consist of Research/Study Result. The results of the research/Study Result are planning products that will be used to build fixed assets such as FS and DED.

\section{RESULTS AND DISCUSSIONS}

Implementation of the intangible asset accounting in the MoPWH which is discussed in this study includes recognition, measurement, termination and disengagement, as well as recording, presenting, and disclosure.

Table.3. Analysis of Implementation of Intangible Asset Accounting at The MoPWH

\begin{tabular}{|c|c|c|c|}
\hline Accounting Cycle & Criteria & Weaknesses & Solution \\
\hline Recognition & $\begin{array}{l}\text { Provide future } \\
\text { economic and/or } \\
\text { social benefits }\end{array}$ & $\begin{array}{l}\text { - Difficulty in determining future economic } \\
\text { benefits for output of research/study results. } \\
\text { - The cost of acquisition of intangible asset in } \\
\text { the form of output of research/study result is } \\
\text { the burden when it occurs. } \\
\text { - Lack of understanding and awareness of the } \\
\text { apparatus on the concept of recognition of } \\
\text { intangible assets in the MoPWH. } \\
\text { - The incomplete provisions or guidelines } \\
\text { governing the accounting treatment of } \\
\text { intangible assets in the MoPWH. }\end{array}$ & $\begin{array}{l}\text { - Improving Intangible Asset } \\
\text { Planning in the MoPWH. } \\
\text { - Improving the Role of the } \\
\text { Inspectorate General of the } \\
\text { MoPWH in the Administration of } \\
\text { Intangible Assets. } \\
\text { - Develop Standard Operating } \\
\text { Procedures (SOP) Implementation } \\
\text { of Intangible Asset Accounting } \\
\text { - Increasing Employee Capacity }\end{array}$ \\
\hline
\end{tabular}

Measurement Using either acquisition costs

Termination and Disengagement

Has no future economic benefits

Recording, Presentation, and Disclosure
Done at the end of each accounting period
There is an expenditure on the elements of intangible asset that should be measured as an expense when incurred, but is measured by the entity as part of the cost.

- Software and research/study results because it has no future economic benefits

- Research/study results that have been used as a guideline for the implementation of physical activities but still stand alone and not yet capitalized into related fixed assets.

Presentation of intangible asset amount and value in the balance of the MoPWH to be overstated
Apply the measurement of all intangible asset generated by the MoPWH based on cost. Reliable cost will occur if the expenses for obtaining the intangible asset are properly identified and documented.

Identify all intangible assets in the MoPWH that can be carried out the disposal process for intangible asset that has no future economic benefits or that does not qualify as intangible asset and capitalizes on the intangible assets owning the asset parent.

Preparing intangible assets accounting guidelines and policies in the MoPWH based on Government Accounting Standard Bulletin Number 17

Parties related to the implementation of the intangible asset accounting in the MoPWH are: (1) the intangible asset producing unit, (2) the Inspectorate General of the MoPWH, (3) the Bureau of State Property Management, and (4) the Finance Bureau. 
The preparation of the SOP proposal for the implementation of intangible asset accounting in the MoPWH comprises SOPs in the planning, implementation and reporting stages of activities as follows:

A. SOP of Accounting Implementation of Intangible Asset in MoPWH at Activity Planning Stage.

SOPs at the planning stage of activities are used to identify potential acquisition of intangible assets that meet intangible asset recognition elements. Parties related to SOPs at the planning stage of activities are the intangible asset producing unit and the Inspectorate General of the MoPWH. The procedures undertaken in the planning stages of activities are as follows:

1) Activity begins with submission of activity plan by intangible asset producing unit.

2) The activity plan is selected by Directorate as the head of the working unit through Planning section to monitor and evaluate the proposed activities.

3) The activity plan that passed the selection of assistance is the basis for the preparation of the Working Budget Plan and Goods of the working unit. Working Budget Plan and Goods which have been prepared then submitted to Inspectorate General of MoPWH for review.

4) The Inspectorate General of the MoPWH conducts a review of Working Budget Plan and Goods which have been prepared by the working unit. The review of Working Budget Plan and Goods is carried out to ensure that budgets in Working Budget Plan and state property needs in working unit have been prepared based on activity plan that pass the selection of assistance.

5) In case of correction to Working Budget Plan and Goods of the working unit, the Inspectorate General of the MoPWH shall return the Working Budget Plan and Goods to the working unit for correction.

6) When reviewing the Working Budget Plan and Goods, the Inspectorate General of the MoPWH undertakes an inventory of the potential and acquisition of intangible asset from each activity plan to be carried out by the working unit and the attributable costs for the acquisition of the intangible asset. Potential intangible asset that has been done inventory will be the basis of supervision by the Inspectorate General of the MoPWH, either through audit, assistance, or review of the MoPWH Report.

B. SOP of Accounting Implementation of Intangible Asset in MoPWH at Activity Implementation Stage.

SOPs at the implementation stage of the activities are used to emphasize the importance of intangible asset measurements of outputs generated at cost. Parties related to SOPs at the stage of implementation of activities are the intangible asset producing unit. The procedures undertaken in the implementation stage of activities are as follows:

1) After Working Budget Plan is legalized in the form of Budget Implementation List, the work unit shall carry out the activities.

2) During the implementation of the activity, Balai through PPK Planning conduct monitoring and evaluation periodically. Monitoring conducted by Directorate through Planning section is undertaken to assess and evaluate activities undertaken by the working unit and monitor the acquisition of intangible asset activities underway. At this stage, Directorate through Planning section should be able to ascertain when the acquisition of intangible asset can be recognized. After Directorate through Planning section states that the output of the implementation of the activity has met the intangible asset recognition criteria, the working unit shall document the evidence of expenditure on the implementation of activities related to the acquisition of intangible asset.

C. SOP Accounting Implementation of Intangible Asset in MoPWH at Activity Reporting Stage.

Intangible asset implementation SOP at the activity reporting stage aims to output intangible asset outputs generated from activities carried out by the working unit reported in the MoPWH Report. Parties related to SOPs at the activity reporting stage are the intangible asset producing unit, the Inspectorate General of the MoPWH, the Bureau of State Property Management, and the Finance Bureau. The procedures undertaken in the activity reporting stage are as follows:

1) Based on the evidence of acquisition of intangible asset, the working unit records the intangible asset generated from the activity. Intangible asset acquisition data is then reported by the working unit to Directorate through Planning section to reconcile the cost of acquisition of intangible asset from the output generated and made the news event.

2) Directorate through Planning section receives intangible asset acquisition data from working unit. Based on these data, Directorate through Planning section creates an internal reconciliation event report to determine intangible assets value of intangible asset acquisition resulting from the activity.

3) Directorate through Planning section perform an inventory of all intangible asset generated by working units which is the responsibility.

4) The Working Unit shall record the amount and value of the intangible asset in the Financial Report and State Property Report of the working unit based on internal reconciliation report issued by Directorate through Planning section. 
5) The Working unit shall submit its respective Financial Statements to the financial bureau and the state property report to the Bureau of State Property Management.

6) The Finance Bureau and the Bureau of State Property Management consolidate the Financial Report and State Property Report of the MoPWH.

7) The Finance Bureau and the Bureau of State Property Management submit the Financial Report and State Property Report of the MoPWH to be reviewed by the Inspectorate General of the MoPWH.

8) Inspectorate General of the MoPWH conducts reviews on the Financial Statements and State Property Reports. At this stage, the Inspectorate General of the MoPWH ensures that the amount and value of intangible asset presented is an accumulation of the acquisition of intangible asset working unit. In addition, reviews are also made of the adequacy of disclosure of intangible asset recorded in the Ministry of Finance's PUPR Financial Statement.

9) After the Financial Reports and State Property Reports are reviewed, the Finance Bureau and the Bureau of State Property Management publish the Financial Statements and State Property Reports.

\section{CONCLUSION}

From the analysis, there are several issues related to the recognition, measurement, termination and disengagement, recording, presentation, and disclosure of intangible asset accounting implementation in the MoPWH.

It is suggested to the Minister of MoPWH to make improvements to the accounting implementation of intangible asset in the MoPWH by:

1) Establishing a special team consisting of representatives of the Finance Bureau, the Bureau of State Property Management, the Inspectorate General, and the working unit to formulate the standard guidelines of the intangible asset accounting implementation policy in the MoPWH that is in accordance with Government Accounting Standards. The standard guidelines regulate internally the intangible asset accounting policies in the MoPWH starting from recognizing, measuring, amortizing, impairing, termination and disengagement, recording, presentation and disclosure of intangible asset. The guidelines also provide Standard Operating Procedures (SOP) of intangible asset accounting implementation in the MoPWH.

2) Instructing Echelon 1 within the MoPWH to instruct the lower-level working unit to identify the cost of acquisition of intangible asset owned, the inventory of intangible asset which needs to be processed for disposal and capitalization of intangible asset which owns the parent assets.

3) Instruct the Inspector General of the MoPWH to order his staff accompanied by representatives of the Bureau of State Property Management to help on the identification and inventory of intangible asset of all working units within the MoPWH.

\section{ACKNOWLEDGMENT}

The author gratefully acknowledges to the Indonesia's National Government Internal Auditor for the funding through State Accountability Revitalization (STAR) Scholarship. Any remaining errors are the authors responsibilities.

\section{REFERENCES}

[1] Badan Pemeriksa Keuangan Republik Indonesia. Laporan Hasil Pemeriksaan atas Laporan Keuangan Kementerian Keuangan Tahun 2015. Badan Pemeriksa Keuangan Republik Indonesia, Jakarta (2016).

[2] NE Wahyuni, H Adam. Analisis Implementasi Standar Akuntansi Pemerintahan Berbasis Akrual dalam Perspektif Teori Institusional: Studi Kasus pada Pemerintah Kota Malang. Undergraduate Thesis, Universitas Brawijaya (2015).

[3] PJ DiMaggio, WW Powell. The iron cage revisited: Institutional isomorphism and collective rationality in organizational fields. American Sociological Review, 48(2) (1983) 147-160.

[4] Republik Indonesia. Peraturan Pemerintah Republik Indonesia Nomor 71 Tahun 2010 tentang Standar Akuntansi Pemerintahan. Republik Indonesia, Jakarta (2010).

[5] Komite Standar Akuntansi Pemerintah (KSAP). Buletin Teknis No. 17 tentang Akuntansi Aset Tak Berwujud Berbasis Akrual. Komite Standar Akuntansi Pemerintah (KSAP), Jakarta (2014).

[6] OC Bunget, RG Blidisel, L Feleaga, IE Popa. Empirical Study of Intangible Assets in Romanian Municipalities. Ekonomie a Management, 17(3) (2014) 136-150.

[7] A Tathagati. Step by Step Membuat SOP (Standard Operating Procedures). Efata Publishing, Yogyakarta (2015).

[8] U Sekaran, R Bougie. Research Methods for Business: A Skill-Building Approach, $6^{\text {th }}$ Edition. John Wiley \& Sons, West Sussex (2013). 